\title{
Problems and Solutions in the Work of College Graduate Teaching Management
}

\author{
Mu-Wei Zhang \\ College of Liberal Arts, \\ Jilin Agricultural University, \\ Changchun, Jilin 130118 \\ 70992810@qq.com
}

\begin{abstract}
Strengthening the college graduate teaching management is an important approach to promote the sustainable development of graduate education. This article is aimed at analyzing the problems existing in the current teaching management of college graduate students, proposing approaches to reinforce the teaching management of graduate students, such as curriculum reforming, the construction of teachers' groups, the service awareness of administrative staff, the teaching management models and incentive mechanisms. Thus, it is very essential to advance the graduate teaching management work with the times, improve the efficiency of graduate management and the quality of graduate education.
\end{abstract}

Keywords—graduate students; teaching management; problems and solutions

\section{INTRODUCTION}

With the increasing of the enrollment scale of graduate students year by year, the complexity of graduate teaching management has greatly increased as well. It has become the key tasks in the current college graduate students teaching management to innovate education and teaching management modes, open up new ways to improve the efficiency of graduate students teaching management.

At present, in most domestic colleges and universities, the mode of graduate teaching management is the second-level management mode. As the first level of administrative department, the graduate department needs to establish relevant rules and regulations of graduate training on the macroscopic level, according to the national plan for the development of education and general teaching goals of schools, to coordinate various works of graduate education management.

As a second-level management department, various postgraduate training departments formulate specific implementations of the national and school policy and responsible for daily management work of postgraduate training, including professional training of graduate students, discipline construction, admission re-examination arrangement of daily teaching, dissertation proposal, school management, organization of oral defenses, management of supervisors, academic exchanges etc.

\section{PROBLEMS IN THE COLLEGE GRADUATE TEACHING MANAGEMENT}

\section{A. The Settings of Curriculum System Being Improper}

A reasonable curriculum should meet the graduate training objectives and the demands of social development for highlevel talents, and also meet the requirements of the development of students' personality [1]. The cultivation of graduate students should put the ability of innovation as the core[2].Graduate education cultivate the creative talents that are willing to listen, to think, to say, dare to doubt, to argue ,through reasonable course settings. While currently, the contents of graduate curriculums of the vast majority of universities have been obsolete, and teachers mostly adopt the "cramming" teaching methods, which can hardly inspire students' active learning and thinking. There is a lack of reasonable cross elective course and trans-disciplinary courses. The establishment of courses is casual, lacking an overall arrangement, largely depending on the subjective willing and research interests of supervisors and academic status, of the subject, detached from requirements of fostering versatile talents that have multi-disciplinary knowledge and skills.

\section{B. The Administrative Staff Having Thin Service Consciousness.}

From the higher level of authorities, to the second-level management departments, part of administrative staff of graduate teaching management lack of patience in dealing with teachers and students, there even are phenomena like dodge, procrastination, prevarication. In the execution of the specific work, they take a "top-down" management mode, cannot stand in the perspective of teachers and students to think and solve problems, cannot play the role of setting up bridges between school and teacher, students, cannot timely collect and analyze the innovative ideas and opinions of vast teachers and graduate students, nor timely feedback to the superior departments, easy to make the teaching management trap into a vicious circle.

\section{The Degree of Participation by Supervisors in Graduate \\ Training and Management Needs to Be Improved.}

Currently, with the expansion of graduate enrollment the number of graduate supervisors is also increasing year by year, more and more young teachers have been absorbed into the tutor groups. But on the facets of training mechanism and training effectiveness, they are not matched in a reasonable 
and optimized way. Compared with the undergraduates, graduate students depend more on the tutors' guidance in learning and scientific research. But many tutors have tooheavy pressure in teaching and scientific research, leading to an imbalance in the distribution of energy, unable to devote into the work of postgraduate training and daily management. Some teachers engage in administrative work, have very limited time and energy to instruct students, resulting in the generation of "sheepherding type" guiding relationship between students and tutors. All the above situations will lead to the students are unwilling to actively communicate with instructors, and it is hard to guarantee the instructors' authority to students, finally leading to the problems of out-ofrange academic morality of students, seriously influencing their studies.

\section{Graduate Teaching Management Modes and Mechanisms Being Not Well Rounded.}

At present, the work of teaching management of most domestic colleges and universities are undertaken by student secretaries led by deans, and the management of students' everyday behaviors is uniformly in charge of the first-level teaching management department--counselors of graduate school . Therefore, postgraduate management teams are relatively dispersed lack of coordination and cooperation with each other. With the continuous expansion of students' cultivation scales, some management work cannot be done according to rules like traditional work. Once met with the problems that cannot be solved by referring to the regulations, the arbitrariness of factitious operation increases, resulting in that a lot of graduate management work have no rules to follow, invisibly increasing the uncertainty and randomness of graduate management. At the same time, graduate students management departments and basic units lack of selfmonitoring and self-evaluation mechanisms, leading to undisciplined work of teaching management staff, lacking of purposiveness and activeness, further directly impacting their efficiency and enthusiasm in work.

\section{EFFECTIVE WAYS OF STRENGTHENING THE GRADUATE TEACHING MANAGEMENT OF COLLEGES AND UNIVERSITIES}

\section{A. Reform the Curriculum System, Improve the Quality of Graduate Education}

The establishment of curriculum systems is very crucial to the quality of graduate training. The university should formulate scientific and reasonable structure of graduate curriculum system, based on professional and disciplinary development and talent training goals. Taking the setting of graduate courses of liberal arts as an example, the setting of most graduates' liberal arts courses requires they complete all the courses in the first academic year, and complete the composition and defense of postgraduate thesis in the remaining two years. However, the large amount of academic courses in the first year greatly reduced the time of students actively participating scientific research and enhancing creative practices, $\mathrm{i}$ while seldom study due to none or little curriculum in the remaining two academic years, and hastily complete thesis before defense. This will necessarily lead to the low quality of graduate cultivation. Therefore, the school should base on their own conditions of student resource, subject status, and students' needs of self-development, timely adjust research postgraduate curriculums, integrate and simplify similar courses of the various specialties, classify and expand the scope of elective courses. In this way, students can select courses that benefit their research according to their own needs, enhancing the breadth and depth of their research contents, improving their professional and comprehensive quality.

\section{B. Graduate Teaching Management Staff Should Change the Management Concept, Strengthen the Service Consciousness.}

The staffs of graduate teaching management are not only managers, but also servicers; need to achieve the organic unity of service and management. The workers of graduate teaching management should change notions, change passive service into active service, to think what teachers and students are thinking, worry about what students worry about. In the face of high-level talents (academic leaders, graduate tutors and graduate students, etc.), workers of graduate teaching management should also have high moral qualities and cultural literacy, promoting the effective implementation of various management works.

Postgraduate teaching management is charged with the missions of cultivating high-quality, high-level talents, the responsibility are significant [3].Responsibility consciousness, whole-situation consciousness is the necessary consciousness for graduate teaching management staff. In specific work, they should detail the responsibility, specify the subjects of responsibility, lay emphasis on the interests of postgraduate tutors and students, graduate education and the development enterprise in doing everything. hey should not seek their own benefits, be slack in work. Postgraduate teaching management staff should closely combine professional goals and the goals of school development, standardize the teaching management behaviors, organize the orderly unfolding of various teaching links, and ensure the continuity and stability of the teaching management.

\section{Strengthen the Supervisor-Responsibility System, Give Full Play to Their Roles of "Teaching Through Actions as Much as Words", "Setting Themselves Examples First".}

In the context of the tutorial system graduate education of our country, the level of the tutors' team is closely linked to the quality of graduate students' academic ability, practical ability and innovation ability[4].The tutor is the first responsible person of the ideological and political education of graduates, not only should guide the students to raise the academic ability and professional quality, but also should shoulder the work of students' education and management, playing roles of guidance and supervision in the whole process of cultivating graduate students. Thus we should strengthen the status and role of tutors in the cultivation of graduate students, specify their responsibility and authority. The tutors' "teaching through actions as much as words", "setting themselves examples first" can form a very special influence and restriction to graduates. colleges and universities should give full play to the initiative of instructors, make them participate in the processes of graduate teaching management. We should establish effective communications between 
graduate teaching management staff and tutors, and listen to and accept the opinions and suggestions of tutor put forwards for the work of graduate teaching management, and give timely feedback to the issues they present. As for the lack-ofexperience problem of new instructors, they should regularly organize instructors to participate in related training activities, to provide platforms for mutual exchange and learning among them, making concerted efforts to improve the quality of graduate education.

\section{Further Improve and Perfect the Graduate Teaching Management Mechanisms and Incentive Mechanisms.}

Management mechanisms are very important for teaching management of colleges and universities [5]. It not only determines the progress of teaching work, also determines the fulfillment of teaching achievement. To guarantee the current postgraduate teaching order, the quality of graduate education, and faculty of management effectiveness, we must establish a management mechanism of clear responsibility, reasonable structure, and clear hierarchy, so as to realize the standardization, institutionalization and routinization of management. We should establish a management team of high efficiency, collaboration, clear-division labor, melts graduate students and mentors into the system, making the management activities closer to the demands of students and teachers, to further standardize the graduate program of teaching management.

Graduate teaching management work at one side relies on the business level of the management staff, at the other side, relies on their working enthusiasm[6].We should establish the basic-level quantified evaluation mechanisms and management mechanisms, objectively evaluate the overall effect of teaching management, and stipulate corresponding measures of rewards and punishment according to the results.
We should connect the evaluation results with employment and promotion, achieve "title" and "post" double implementation, provoke the working enthusiasm of management staff, and enhance the management level of performance and quality of talent training, to ensure the sustainable progress of cultivating postgraduates.

\section{CONCLUSION}

With the development and progress of the highereducation enterprise, the continuous expansion of the scale of postgraduate education, the work of college graduate teaching management is also moving forward in the continuous exploration. Teaching management staff should further be studied, have a strong sense of responsibility, service consciousness and overall-situation awareness, promoting the teaching management work to keep pace with the times and develop prosperously.

\section{REFERENCES}

[1] Li Yulan.The quality content and standard of postgraduate education curriculum, the research on [J]. graduate education research.2010 (5).

[2] Ding Yukui Wang Haidan, a few thoughts on the innovation ability of graduate students in [J]. education.2011 (11).

[3] Tang Yun. Strengthen the graduate management cadre team construction work of.2012 [J]. (7).

[4] Gao Wenhua, Liao Heping, Wang Kexi. Study on the cultivation of innovative ability of university graduate students [J]. degree and graduate education.2011 (9)

[5] Tao. Strengthen the teaching management of colleges and universities to cultivate high quality excellent graduate [J]. higher education journal, 2015 (8).

[6] Jiao Lili. Research on the basic level teaching management of the graduate students in the University [J]. education observation. 2015 (12) 